\title{
Geomorphologic regionalising of the Romanian territory in the space-chronologic system context
}

\author{
Octavian Mândruţ \\ The "Vasile Goldiş" Western University of Arad \\ Arad, Romania \\ octavianmandrut@yahoo.com
}

\begin{abstract}
The geomorphologic regionalising of the area attached to our country have evolved in time in relation with the level of knowledge of its relief and substrate. There is regionalising at various levels (from the entire territory to morphosites), a different denomination of the units of relief, but there are also patterns which are considered acceptable.
\end{abstract}

Currently, it is possible to build an improved objective pattern which may consider among others:

- The relatively recent changes of the research of the geologic substrate through the prism of the tectonics of the active (micro) plaques in the area of our country; relief;

- The scalar size of the taxonomic organization of the

- The relative primate of the chronologic/ temporal component;

- The option for a regionalizing pattern between: the typological model (the similitude of the forms of relief), the morpho-chronologic one (temporal synchronisation), the pattern of the foundation structure (the "tectonic" pattern), the model of the composition of relatively homogenous elementary surfaces (“morphographic” model) etc.

Keywords- morpho-chronologic model; extra-Carpathian area; Carpathian area; the taxonomy of the relief

\section{INTRODUCTION}

The spatial-temporal pattern of the regionalisation starts from the establishment of two large geomorphologic area which are significant at meso scale as follows: the extra-Carpathian area (on an old foundation) and the Carpathian area (on an alpine orogeny structure); each field has more structuring regions, uneven as spread, but relatively homogenous as typology and morpho-chronology.

The pattern proposes an order for analysing the regions, such as: for the extra-Carpathian field, starting with the oldest dried reliefs, and for the Carpathian area, starting with the most expressive region. The internal taxonomy comprises certain updated elements and an apparently simplified denomination.
The details and descriptions of the regional units are presented in a recent paper on the topic ("Romania Regional Geomorphology”, 2015).

\section{Models of Regionalisation}

There are more possibilities for approach of the regionalising matter, depending on certain criteria considered as determining or more significant. Two methodological principles of approach can be considered:

- From subordinated units to smaller composing units, until the level of some microsites (this regionalising may comprise a certain number of few levels, starting from relief sphere to the morphosite). This procedure has an accentuated deductive character, resulted from a detailing process;

- From minimal relevant basic areas to the relief sphere as a whole. For the territory of our country, this would be possible from areas of about $1 \mathrm{~km}^{2}$ to the entire territory of our country which results in a succession of inferences with hyphenated inductive character.

For the first methodological option, there are several possibilities of regionalising, such as:

- Based on a predominantly typological criterion (starting from the main groups of genetic types of relief);

- $\quad$ On areas determined by the vector of superficial flow (thus on morpho hydrography pools);

- $\quad$ By combining the typology item with a certain spatial continuity (resulting relatively homogenous areas, based on a certain criterion, but heterogeneous, based on all internal components);

- The introduction of the time vector and of the substrate of the current relief, which induces a typology (and a regionalisation) while making visible the chronologic size (from the oldest substrates and forms of relief, with a quasihorizontal character - platform areas, cratonized, to the orogeny structures); in this context, we 
mention the originality and relative actuality of the evolving pattern built by I. Al. Popescu - Voiteşti [1];

- Granting the predominant part to the substrate, by delimitation of two major types: platform areas (with superposed relief of more recent age) and orogeny areas (the Carpathian system, formed in the alpine orogeny).

I have presented in a more detailed paper [2] the above presented main possibilities of regionalising. The current model considers to building a regionalising which to highlight the primate of the territory age (which is a reflection of the type of structure and foundation), regardless if a relief carrier is at the surface or it is covered by new sedimentary structures.

\section{SUBSTRATE AND RELIEF}

From the analysis of any significant morphostructural map or of the papers and maps rendering also elements of the foundation, it can be noticed that the territory of our country is at the contact between relatively rigid parts (which belong or had been part of the East European platform) and orogeny areas, situated on the edges of the first one, comprising structures of the AlpineCarpathian system.

The geology works [3] start the analysis of the territory with these platform structures by which the orogeny regions are studied and presented. We believe that the current model does not represent a copying of this vision, but it is just an insertion of the relief seniority (and sometimes even of the subjacent area), as element of origin of the regionalising.

In the same time, we mention that the geomorphologic regionalising performed by geographers who, invariably, start from the Oriental Carpathians and end with the Danube Delta, have an internal stereotypy which is hard to be further sustained.

The modern papers highlight a lot on the temporal side in explaining and describing the relief. The image of the foundation of our country relief, performed by geological and geophysical studies [4], [5], [6] highlight a certain situation which allows for framing this area in the general evolution of the terrestrial relief, according to the plate tectonic theory.

As the movement of the tectonic plate is the main drive in forming the ensembles of the relief sphere (and of its internal components), it is absolutely necessary to consider more predominantly and visibly the geo-tectonic component of the relief forming and evolution.

The current vision of the regionalization starts from the premise of the identification of two major areas on the Romanian territory, with significance for the geologic, tectonic and geo-morphologic area of the Europe:

- The platform area, situated in the Eastern continental part of the Europe which is formed by elements of the prior stand of the alpine orogeny; this is part of the South-Western edge of the East European continental platform and worked as a relatively rigid area for a very long timeframe (0.6 billion years), with elevations and descents, followed by sedimentary series on which the current relief attached;

- The orogeny area, belonging to the alpine Europe, generated during the respective orogeny, comprising a mountain system (the Carpathians) tectonically organised in thrust layer with two associated microridges (Transylvanian microridge and the Pannonia one) covered by sedimentary layers, on which the current relief developed.

As the geo-tectonic and geological researches indicate, the Carpathian arc comes from the regeneration of the continental tectonic edge and it looks like successive sheets (different in names and age)

Starting from this general finding, we have to admit that we find ourselves in front of two geo-morphologic domains belonging to these relatively distinct areas, which are in collision. This type of opinion has been issued with almost six decades ago [7].

\section{GEO-MORPHOLOGIC AREAS AND REGIONS}

The extra-Carpathian area has as common item the existence in depth of some Proterozoic and Palaeozoic structures (of platform), organised in few identifiable areas:

- The East European foundation (the Moldavian platform), for a large part of the substrate of the current relief of the Moldavian Plateau, continued to South-West and South with the Scythian Platform edged, at its turn, further by a depression area (the Barlad Depression); a sedimentation and drying process occurred on this subjacent structure during the Cretaceous - Pliocene interval, with the formation of the current relief;

- The Moesian Platform, located in the foundation of the Romanian Plain, is a structure comprising in its depth rocks alike to the Carpathian-Balkan system; in its Eastern part, the Moesian platform and the South Dobrogea Platform (forming together a microplate) descend in a inclined plan in front of the Sub Carpathians and of the Carpathians of Curvature causing the earthquakes in the Vrancea area and the area of tectonic and subsidence descent from the exterior of the Sub Carpathians of Curvature; the relief of the Romanian Plain foundation is very complex and interesting considering the evolution [8]

- The Dobrogea foundation occurs at the surface in the system of green shale structures which form the oldest relief placed at the surface;

- The North Dobrogea orogeny is currently a cratonized region, though, it represented in the past an area of sedimentation and folding located between the Moldavian Platform (situated in the North) and the Moesian Platform (situated to the South); being comprised between the platform areas, the North Dobrogea orogeny has currently the function of rigid geo-morphologic substrate;

- Currently, there is a descending area between the foundation of the Moldavian Plateau (the EastEuropean Platform) and the Dobrogea - Moesian foundation, named the Pre Dobrogea Depression 
or the Barlad Depression; its existence reflects indirectly in the current relief.

The Carpathian area comprises the Carpathian orogeny and the internal depressions (which superpose to the Transylvanian and Pannonia micro-plate).

This area comprises the following large divisions:

- The Oriental Carpathians (Northern and Central parts), with the three partial structures;

- The Carpathians of Curvature, almost predominantly formed by flysch, with individualised geological structure, relief and functionality in the mountain range;

- The Southern Carpathians (including the Carpathians of the Banat and the Mehedinti Plateau, by the geological structure, and also by position, links, and forms of relief), formed by crystalline schist, granite intrusions, thrust structure and patches of Mesozoic sedimentation;

- Northern Apuseni, a genuine erected part between the two lowered microplates (Pannonia and Transylvanian);
Southern Apuseni (a geosyncline structure) formed by volcanic rocks and flysch;

- The Transylvanian Depression, developed over the Transylvanian microplate, sedimented in long time (Cretaceous - Pliocene), with a relief reflecting the way of arrangement of the rocks of the sedimentary substrate (but less the relief of the foundation); this microplate forms a descended area of the Carpathian crystalline; it looks like an interior depression, and, considering the relief, as an extended sediment intra-Carpathian depression with hillside relief;

- The Western Hills and the Western Plain represent an association of slightly sloped or horizontal shapes, developed on a lowered foundation of the Pannonia microplate; the Transylvanian and the Pannonia microplates are in contact in the proximity of the Meses-Preluca intra-Carpathian yoke;

- Obviously, the Sub Carpathians represent "the last orogeny episode” in forming the Carpathian range, having a much more complex character in continuing the Carpathians of Curvature; the Sub Carpathians follow in a very general way the periCarpathian fault line.

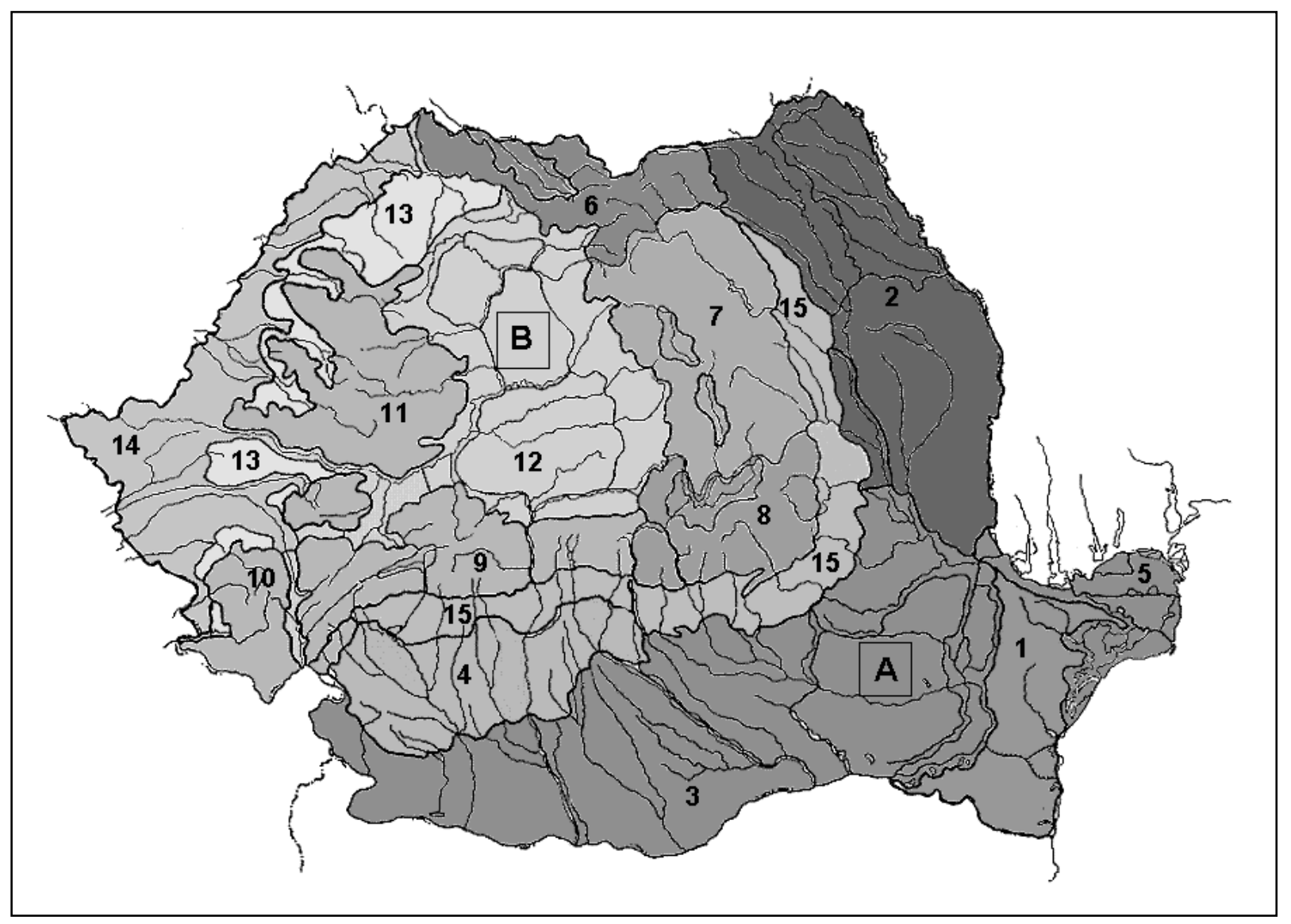

Fig. 1. The Major Geo-Morphologic Area (A, B) and the Component Regions (1 - 15). 
A. The extra-Carpathian area - on rigid, lowered structures covered by sediments and predominantly horizontal relief; it comprises several regions, such as:

1. The Dobrogea Plateau - on the structure of the Central and South Dobrogea Platform and the NorthDobrogea orogeny with a lowered area (the east side of the Romanian Plain)

2. The Moldavian Plateau - predominant on the structure of the Moldavian Platform

3. The Romanian Plain (Centre and West) - on the structure of the Moesian Platform

5. The Danube Delta - on the structure of the preDobrogea Depression

B. The Carpathian area - on the Carpathian orogeny, including the interior microplates with the component regions:

6. The Maramures and Bukovina Carpathians - with three areas and trans-Carpathian flysch

7. The Moldavian-Transylvanian Carpathians - with three parallel areas

8. The Carpathians of Curvature - on an almost exclusively flysch structure

9. The Southern Carpathians - on an alpine orogeny structure and thrust sheets

10. The Banat Carpathians - on the same structure with the Southern Carpathians

11. The Western Romanian Carpathians - on a predominantly crystalline structure (Northern Apuseni), and composite rift one (Southern Apuseni)

12. The Hillside Depression of Transylvania - on the structure of the Transylvanian micro-plate

\section{The Western Hills}

14. The Western Plain - especially on the structure of the Pannonia micro-plate

C. The transition zone (without being an area) comprises the Sub Carpathians (15), with aspects of incipient orogeny, and the Get Piedmont (4), on a mixt structure; this area masks the peri-Carpathian "fault line".

The presentation of the two areas (A and B) represents much more than a simple collation.

The geographers' geo-morphologic regionalising [9], [10], [11], [12], [13], [14] details a lot the regional image.

There are territorial units of smaller area inside each region $(1-15)$. Their names are different (by different authors) and there are references to very small areas with names without obvious justification. We have renounced to some denominative [2] mentions for these units as they would overcharge with local examples an already extended taxonomy.

Each region $(1-15)$ is presented by a unitary structure comprising: the geo-morphological specificity (position, extension, identity, genesis), the geomorphological characterisation (substrate, evolution, morphography, morphometric, morphological structure, types of relief), the internal divisions.

\section{REFERENCES}

[1] I. Popescu Voiteşti, Evoluţia geologico - paleogeografică a pământului românesc, Cluj - Napoca: Institutul de Arte Grafice „Ardealul”, 1936. (in Romanian)

[2] O. Mândrut, România - Geomorfologie regională, Arad: Ed. Univ. Vasile Goldiş”, 2015. (in Romanian)

[3] V. Mutihac and G. Mutihac, Geologia României, Bucharest: EDP, 2010. (in Romanian)

[4] Șt. Airinei, Radiografia geofizică a subsolului României, Bucharest: Editura Ştiinţifică şi Enciclopedică, 1980. (in Romanian)

[5] R. Botezatu, Modele geofizice ale alcătuirii geologice a României, Bucharest: Editura Academiei, 1982. (in Romanian)

[6] M. Săndulescu, Geotectonica României, Bucharest: Editura Tehnică, 1984. (in Romanian)

[7] P. Coteț and C. Martiniuc, „Geomorfologia” în Monografia geografică a R.P.R., vol. I., Bucureşti: Editura Ştiinţifică, 1960. (in Romanian)

[8] D. Paraschiv, „Suprafaţa de denudare înhumată premesogeană (relieful cadomian) la exteriorul Carpaţilor Româneşti”, în Studii şi Cercetări de Geografie, Tom XLVII - XLVIII, 2000 - 2001, Bucharest: Editura Academiei Române, 2001. (in Romanian)

[9] V. Mihăilescu, „Marile regiuni morfologice ale Românei”, în BSRRG, vol. L, 1931. (in Romanian)

[10] P. Coteţ, Geomorfologia României, Bucureşti: Editura Tehnică, 1973. (in Romanian)

[11] Gr. Posea, Geomorfologia României, Bucureşti: Editura Fundaţiei „România de Mâine”, 2003. (in Romanian)

[12] L. Badea, (coord.), Unităţile de relief ale României, vol. I - V, Bucharest: Editura Ars Docendi, 2001 - 2015. (in Romanian)

[13] Gr., Posea and L. Badea, ,Regionarea geomorfologică a teritoriului României”, în Buletinul Societăţii de Stiințe Geografice, serie nouă, vol. VI (LXXVI), Bucureşti, 1982. (in Romanian)

[14] Al. Roșu and D. Bălteanu, „Caracterizarea cantitativă și clasificarea unităţilor geomorfologice din România pe baza varietăţii reliefului”, în Terra, I (XXI), 1, București, 1969. (in Romanian) 